\title{
Learners transition Rates from Primary Schools to Secondary Schools in Kenya
}

\author{
Josephine Kagwiria Kirimi, Ndirangu Beatrice Waiyego \\ School of Education, Mount Kenya University \\ jkirimi@mku.ac.ke,joskirimi@yahoo.com
}

\begin{abstract}
Basic literacy and numeracy skills are key to development in most countries. There is conclusive research evidence that the provision of quality basic education to a Country's population is crucial to achievement of rapid and sustained National Development, elimination of poverty, ignorance and diseases. Primary education in Kenya has been free following the government decree of UPE causing high enrolment in primary schools although the transition of pupils to secondary schools remains low in Ruiru District. The purpose of the study, therefore, was to investigate why there has been low transition of pupils from primary to secondary schools in Ruiru District despite the implementation of Free Primary Education in Kenya. The study was guided by the System Theory which is basically concerned with problems of relationships, of structures and of interdependence, rather than with the constant attributes of objects. The study established that fund released by the government was not adequate to cater for human resource, physical facilities and teaching / learning resources. However, to ensure learners graduate in class eight and transite to secondary school, the study concluded that some schools introduced school feeding programmes to enhance retention, the government should allocate adequate funds to schools to ensure that Free Primary Education programme run smoothly without compromising quality of education which eventually influence learners' transition rate from one level to another; parents and community members should fully support pupils education and school development projects among other recommendations.
\end{abstract}

Keywords: Transition rate, Universal Primary Education, Free Primary Education, Primary Education, Secondary Education

\section{INTRODUCTION}

\subsection{Background to the Study}

Achieving UPE by ensuring all boys and girls complete a full course of primary schooling is one of the Millennium Development Goals as pledged by 189 United Nations Member States. The National Rainbow Coalition (NARC) government introduction to Free Primary Education (FPE) was a commitment to realize the Universal Primary Education, (UPE) and Education for All (EFA) by 2015. On 10th January 2003 the Minister for Education appointed the Free Primary Education (FPE) Task Force. Its main objective was to assist the Government to develop appropriate responses for implementing FPE and to outline concrete guidelines for smooth and effective implementation. The taskforce was mandated to identify the immediate and long term issues on the implementation of FPE, including the revision of the curriculum and other relevant concerns related to FPE.

Free Primary Education allows all Kenyan children to education without discrimination. It was launched by the Minister for Education on $6^{\text {th }}$ January, 2003. It was a response to the World Conference on Education for All held in Jomtien, Thailand in march 1990 which emphasized the importance of extending basic education to the risk learners and minority groups. There was an appeal to countries to take a fresh look at the education offered to different ethnic, cultural and religious groupings within countries, people with disabilities and gender issues. There was also the World Education Forum held in Dakar, Senegal on $26^{\text {th }}-28$ th April 2000. The purpose of the forum was to review the progress made since the world conference on Education for All in Jomtein, to reaffirm commitment to EFA and to map out appropriate strategies and resources to meet the goals of EFA (UNESCO, 2002).

The Kenya government was one of those signatories that agreed and signed the recommendations of these two international meetings. It considers the attainment of UPE as a development strategy. The literate population is the key to the overall development of any nation, it therefore removes obstacles 
that hinder children of school going age from accessing and completing primary education as is the case in many urban areas and the Arid and Semi-Arid Lands (ASALs). The education has a shared responsibility of government, parents, teachers, communities, political leaders, religious organizations, private investors, development agencies among others. Fees and levies for tuition in primary education have been abolished since 2003 where the government and development partners paid Kshs.1020 for primary education child. Over age children who show up at schools should be enabled to attend. Kimani Maruge Ng'ang'a enrolled at an age of over 80 years because he wanted to learn how to read and write. FPE has attracted many Kenyan children in the right of education which removes diseases, ignorance and poverty in the society.

Secondary education is the stage of education following primary school. In some countries it includes the final stage of compulsory Education. Secondary education is characterized by transition from primary school for minors. Transition is a major milestone for children and creates big changes in their life, development and education. Secondary education gives an opportunity to children to be challenged and develop the valuable skills that will take them to adult life. Leaving the familiar surroundings of primary school is normally both exciting and daunting to children. On 12 February 2008 , the then president formally launched the free secondary education programme in line with pledge he had made earlier before. The progaramme was to target a higher enrolment whereby Kshs 10,265 per student per year was to be paid by the government for tuition fees. The parents were to meet the boarding costs and buy uniforms for their children. The programme was to relieve the poor and marginalized communities from accessing education equally.

\subsection{Statement of the Problem}

From 2003, primary education in Kenya has been free following the government's decree of UPE. Enrolment of pupils in primary schools has risen due to the implementation of FPE. The rate of transition of pupils from Primary to Secondary schools in Ruiru District has remained low despite implementation of free education in primary and secondary level. This has raised a lot of concern to the stakeholders especially the government, teachers, parents, donors and the learners themselves as to why very many pupils do not join secondary schools causing necessity for a research.

The table below shows standard eight transition late for the past three years in Ruiru District.

\begin{tabular}{|l|l|l|l|}
\hline YEAR & ENTRY & TRANSITION & PERCENTAGE \\
\hline 2010 & 3771 & 1712 & 43.74 \\
\hline 2011 & 4025 & 1844 & 43.98 \\
\hline 2012 & 4376 & 1926 & 44.01 \\
\hline
\end{tabular}

\subsection{Theoretical Framework}

The research revolved around the System Theory. It was developed by biologist Ludwig Von Bertalanffy in 1968. Little John (1983) defines a system as a set of objects or entities that interrelate with one another to form a whole. The system theory views an organization as social system consisting of individuals who cooperate within a formal framework, drawing resource, people, finances from their environment and putting back into that environment the products they produce. Human capital influences government commitment to invest in education through establishment of learning institutions at all levels and financing of education. After the attainment of independence in 1963 the Kenya government, lacked the personnel needed to replace the Europeans in the civil service and other sectors of the government. The government, therefore, undertook to provide education as a way of creating a pool of human resources to promote economic growth. The setting up of education commissions and prioritizing education's needs in the subsequent development plans proves the government's effort to invest in its people. The declaration of Free Primary Education in 2003 and Free Secondary Education in 2008 is a milestone in Kenya government's effort to invest in human capital.

The system theory maintains that an organization does not exist in a vacuum. It does not only depend on its environment but also acts as the society in the economic system to which it belongs. Primary and secondary schools are open systems hence they respond to the external influences as they attempt to achieve their transition objectives. The implementation of FPE is an example of change from the outer environment. 


\section{Literature REVIEW}

\subsection{Introduction}

\section{Free Primary Education}

The global movement to promote the goals of Education for All (EFA) took root during a conference which was officially called world summit for children, held in Jomtien, Thailand, on June 1990 (Sorobea 1992). In the conference, comments on UPE identified education as a fundamental human right. During the World Education forum in Dakar, Senegal in April, 2000 by the world community, consensus was reached to ensure that by 2015 all children will have access to and complete free and compulsory primary education of high quality.

In Britain, basic education has been given to learners in primary and secondary school (World Bank, 2001). Providing universal compulsory education has been successful. In North America, a state subvention of basic education began in $19^{\text {th }}$ century after the establishment of local schools. This was to promote access and also to establish length of stay in school. The state as noted by Kemmerer (1994) subsidized the Local Education Authority (LEA) as an incentive to start new schools. The state started with flat grant approach and later moving to foundation programme approach which recognized a joint state responsibility of financing a minimum basic education programme. This would produce a certain percentage and the state to give a total amount required for each pupil.

In 1960, at a regional meeting of representatives of Asian member states of UNESCO held in Karachi, plans were made for UPE in Asia and the Far East (Bishop, 1994). The plan was to provide universal, compulsory and free primary education in Asian countries within the twenty-year period $1960-1980$. Primary schooling facilities for at least 7 years duration was to be extended to every child in the school-going age group by the end of 1980. This was a bold undertaking. Bishop (1994) notes that, for the fifteen countries covered by the plan, the total population was estimated to increase from 774 million in 1959/60 to 1.185 million in 1980. The number of children of school-going age controlled in primary school world-wide rose from 62 million in 1960 (84\% of the school-going population) to 270 million (20\% in 1980) (UNESCO 2002).

\subsection{Free Primary Education in Africa}

After independence, African countries sought to invest in education as it was the most appropriate tool for achieving desired social, economic and political development. The conference of African states on the development of education in Africa held in Addis Ababa in 1961 recommended that primary education should be universal, compulsory and free by 1980 (Bishop,1994) irrespective of the philosophical positions of many African countries. There is a clear indication that each country has had phenomenal growth in educational development and consequently in financial education (Fufunwa \& Aisiku, 1982).

According to Sifuna (1996), education in Africa had two main objectives. They were to furnish future manpower with requisite skills and knowledge and also inculcating values that enrich lives and maintaining cohesive productivity. To achieve the objectives highlighted above, governments opted for different education models. One of them is the social demand approach commonly known as Free Primary Education (FPE). As illustrated, it was the favourite education model for most African governments as it ensured everybody got education. The approach was also liked because it ensured economically disadvantaged individuals and those from ASALs and other marginalized areas got basic education. However, FPE brought about a high demand for education whenever implemented. This caused strain on available resources despite the fact that the programme had significant socioeconomic advantages. The demand for education across the continent resulted in facilities being rendered inadequate. Pupils subsequently made shift structure. Learning facilities such as books, chalkboard and reference materials were overstretched thus resulting to low quality education.

According to UNESCO (2002) Ghana, for example, educational challenges brought about by the implementation of FPE in Africa were further observed in Ghanaian FPE programme on Africa and happened to be one of the most successful in the continent. However, the Ghanaian FPE Programme has been regarded with skepticism by a UNESCO study (1987-1998) that investigated the success of the programme. The study found that the parents did not consider education as free as propagated by the Ministry of Education in Ghana. After reviewing the quality of education in Ghana UNESCO 
realized that education in rural areas was lower in quality than that of urban areas. This was attributed to lack of textbooks, poor teaching skills, excessive loss of instructional time, an overloaded syllabus, an appropriate approach to non-traditional subjects, poor supervision and lack of motivation for teachers in public schools.

The study recommended the enactment of laws to prosecute parents who used their children as child laborers instead of taking them to school. The study concluded that Ghanaian children in rural areas did not have contact hours with teachers for effective learning and that $95 \%$ of pupils were not mastering basic skills in mathematics and English. The study also realized there was irregular distribution of textbooks. Meanwhile in Ethiopia, Oumer (2008) notes that FPE implementation strategies created better opportunities for communities to contribute to issues. This was a step towards creating a sense of ownership and facilities continued to expand with the help of government funding, donors and community contributions. The government increased educational spending by 5\% GDP reducing non-physical facilities in Ethiopia.

Similarly in Malawi the government of Malawi recognized access to high quality basic education as a means of eradicating poverty for desirable future development as a catalyst for social, economic and industrial development. The government of Malawi introduced FPE in 1994/95 academic year with the ultimate aim of making it compulsory and made wearing of uniforms not compulsory. This was in a bid to ensure that no one is denied access to primary education because of uniform. As a result of the introduction of FPE in Malawi, enrolment increased from 1.9 million to 3.2 million, and after stabilization, dropped from 3.2 million to 2.9 million. As noted further a number of achievements have been made when Malawi increased its contributions to FPE from 49\% (1993/1994) of the current budget to 61\% (1998/1999). The introduction of FPE resulted to human resources shortage leading to the decline of the quality and internal facilities in the Education system. The serious shortage of classrooms led to high teacher-pupil ratio of 1:127 (1997) against the National Standard of 1:60. As a result, most classes were held under trees. The average dropout rates for 1998 and 1999 were 11.9\% and $11.77 \%$ respectively where more boys drop out between grades 1-4 while more girls drop out in upper classes. High repetation rates and HIV/AIDS also impacted negatively on the primary education system of Malawi (wikipaedia)

\subsection{Free Primary Education in East Africa}

The three East African countries having a lot in common have made great efforts towards implementation of FPE policies. According to Rindel (2003), the Government of Uganda, introduced the UPE in January 1997. It was one of the developing countries to introduce UPE, well before the Millennium Development Goals (MDGs) was designed. Education was seen as an important foundation of the Poverty Eradication Action Plan (PEAP). Tuition fees were abolished for 6-12 years old and this was intended to apply to a maximum of 4 children in a family. In addition, disabled and orphaned children were to be given special consideration. It was applied virtually to all children in this age group. Primary enrolment in 1996 was 2.7 million. By 2002, this had surged to 7.2 million pupils. Gross enrolment growth in 1995 was $74.3 \%$ and by $2000 / 1$, gross enrolment had reached $135.8 \%$ indicative of the considerable number of over and underage pupils enrolled. Net enrolment in the same year was $109.5 \%$ and therefore, UPE had been achieved. The commitment to UPE can be seen in the budget allocation to education sector whereby in 1992, education comprised $12 \%$ of the governments' budget and by 1998 , it had reached $25 \%$. This figure has been relatively stable since that time. The goals of EFA comprise of the universal enrolment. This information consider Ugandan achievements' need to be emulated according to the impacts that have been identified both in the MidTerm Review (MTR) and the evaluation of impact of UPE implementation (Government of Uganda, 2003). Both documents address candidly constraints, opportunities and adverse impact ahead in moving from UPE towards FPE. The government of Uganda did not attempt to introduce FPE in the first place. Most of the resources went to school construction, instructional materials, teacher recruitment and also recurrent expenditure. On the other hand, family household expenditure on education remained on clothing, exercise books and school fund contributions. In this case, MTR points to the drastic decrease in enrolment during the transition from grade 1 to 2 . This might relate to the fact that schooling is simply not affordable to those who do not earn cash income.

\subsection{Free Primary Education in Kenya}

Since independence, the Kenya government has pursued policies aimed at expanding and improving the quality of education. Various commissions have been set up and have emphasized the need for 
government of Kenya to support education. For example, in Sessional paper No. 10 of 1965, the government committed to eradicate ignorance, poverty and disease. In 1971, presidential decree abolished tuition for ASALs. The second presidential decree on $12^{\text {th }}$ December, 1973 declared FPE from classes 1-4. Classes 5 to 7 were standardized all over the country to pay Kshs60 per year. The enrolments surged from 1.8 million in 1973 to 2.71 million at the beginning of 1974 . This made the government to employ 25,000 untrained teachers to cope with the problem of the increased enrolment (Republic of Kenya, 2003).

The abolition of school fees are some of the key indicators of the government commitment to provide UPE to the children. Increased enrolment in subsequent years contained the government's ability to fully meet the needs of schools and pupils. For this reason, the cost sharing programme was reintroduced (Sorobea, 1992) which was a recommendation in Kamunge report (1988). The programme shifted the entire burden of books provision to the parents when the government of Kenya abolished Kenya School Equipment Scheme (KSES) in 1989. The parents would also supplement the government funds e.g. building fund, activity fees, watchman fees, school uniforms, desks and examination fees (The international year book of education 1965: 204-205).

According to NARC Manifesto (2002), it had promised to implement FPE in its pre- election pledges if it won. The win thereafter made the government to introduce the FPE. On $6^{\text {th }}$ January 2003, there was launching of free and compulsory Primary Education (MoEST, 2003). This entailed the abolition of tuition fees as part of the increasing costs of education to parents which had accounted largely for the decreasing primary and secondary schools enrolments in the 1990s (Rindel,2003). Following this announcement, enrolments surged from about 6 million to about 7.2 million pupils, resulting in a gross enrolment of $104 \%$ compared to $87.6 \%$ in 2002 . The government funds were channeled to individual schools through the districts offices. The money disbursed was in accordance to the number of pupils in a school. A study conducted by UNESCO (2005) revealed that there are several factors contributing to management of FPE.

\subsection{The Government Factor}

According to MoEST (2003), after 2002 general election and the FPE was implemented the enrolment of primary schools saw an increase of 1.5 million children. This meant the government had to increase its expenditure in catering for Administration and also for the recurrent expenditures. The child was meant to have sufficient time in school by staying for eight uninterrupted years in order to achieve the UPE and FPE goals. Donors were very helpful in supporting and contributing to FPE implementation. They included; World Bank which contributed 3.7billion shillings, UK contributed 1.6 billion, OPEC contributed 1.1 billion while Sweden contributed 430 million shillings (Daily Nation, July 2003).

The disbursement of FPE funds was done according to the supplies as advised by the government. The amount was put into two bank accounts for each primary school in the country. Account 1 was School Instructional Materials Bank Account (SIMBA).

Account 2 was the General Purpose Account (GPA). SIMBA was allocated for instructional materials like textbooks, exercise books, supplementary leaders and reference materials, pencils, dusters, chalk, registers, charts and wall maps. The GPA allocation included; support staff wages, repairs and maintenances, school activities, quality assurance, local travelling and transport, postage, telephone, electricity and contingencies. According to MoEST (2003), each pupil was to receive Kshs.1,020 in a financial year and the amount was to be disbursed in two installments. As the money was disbursed, there was a national monitoring alongside, in all public primary schools for accountability of FPE funds in September 2005. During the exercise, the headteachers were to be in schools and provide documents including; analyzed cash books since the implementation of FPE, Bank statements for the two accounts, SIMSC minute books, files containing deliveries, invoices and payment receipts, issue/receipt registers, TSC green forms, past and present class attendance register, SMC minute book, school logbook and other documents supplied by the Ministry of Education.

During the financial year 2005/2006, each child was entitled to Kshs.1,020 to be released in two installments. First Installment was released in December, 2005. Then there was a second disbursement of the Account II of the financial year 2005/2006 of Kshs. 185.00 per child which was released on $5^{\text {th }}$ May, 2006. In 2005/6, it was noted with concern that the pupil teacher ratio had gone up to 70:1 making the FPE programme ineffective thus affecting the quality of education in primary 
schools. But, the programme had given children from poor families, orphans, the girl child and the other vulnerable children an opportunity to have education. Release of second disbursement of 2005/2006 financial year, Account 1 was released. A circular to school heads of the same was sent on $10^{\text {th }}$ July, 2006. The amount was Kshs. 300/= per child. (MoEST, 2006)

The second GPA disbursement for the financial year 2007/2008 of Kshs. 185.00 per child was released and circular for the same sent on $14^{\text {th }}$ May, 2008. The second SIMBA disbursement of FPE funds in 2007/2008, financial year of Ksh. 250 per child was released (MoEST,2008). The information above is an example of the government's effort through the FPE provisions of the funds up-to-date. The disbursement of the total amount released to primary schools depends with different schools as they have different enrolments.

\subsection{Management and Administration of the School Factor}

According to Mbiti (2007), the chief executive of a school is the head teacher. The success of any school depends on how effective the head teacher is as an administrator. The head teachers therefore will find themselves with responsibilities, commitments, problems and in most cases less free time. They become responsible for delegating duties. They should realize that performance and transition from primary to secondary schools can only come through teamwork of teaching and nonteaching staff, pupils and the community. His/her employer expects high quality work, loyalty and integrity and therefore, must conduct him/herself in a manner that creates good public image.

Muchira (1988), in a study of leadership effectiveness found that principal's leadership style was significantly correlated to the principal level of evaluation. The head teacher is in control of teachers and delegates them school duties. The relationship between the head teachers, teachers, students and non-teaching staff members depends on the head teacher's leadership style. The leadership style helps create conducive learning environment as discussions are encouraged and learners' views listened to. Griffins (1994) emphasizes that the students must effectively be involved in the administrative system of the school.

The introduction of FPE in 2003 was a commitment to realize UPE by 2005 and EFA by 2015. The government and the development partners are meeting the cost of basic teaching and learning materials, wages for critical non-teaching staff and co-curricular activities. The government considers the provision of FPE as central to reduction of poverty, disease and ignorance. The provision should, therefore, be a spirit of partnership where everybody has clear roles to play (MoEST 2003).

According to MoEST in Human Resources (1999), the head teacher in the school is charged with the responsibility of managing the FPE resources whatever tangible and intangible, consumable or nonconsumable. The resources include financial, physical facilities, time, school projects and programs, school offices and also human resources. The head teacher is the principal accounting officer for the school's FPE funds. He is the lead person in planning and directing school activities and therefore, must be active in determining, mobilizing and acquiring FPE financial resources. He must acquaint him/herself with the principles of governing sound management of the funds. He must keep proper records of all finances. All finances should also be used for the benefit of the pupils where approval is done by the SMC. Funds disbursed by the government must be receipted for auditing by the government agent at later time. This makes any expenditure to be made on a payment voucher. Cash in hand must not exceed the amount stipulated by government's regulations. All these are done according to the allocation of the government funds to all public primary schools in Kenya. The head teacher is the manager on ground on behalf of the government and ensures that all FPE funds and its programme succeed. To ascertain this, the government mandates the DEO and QASO officers to inspect and see the program's development is observed.

\subsection{Learners Factor}

\subsubsection{Gender}

According to MoEST (1999) Gender basically means social interaction between males and females. The challenge for the head teacher is to put in place conditions which provide for equal opportunities for both men and women. Empowerment for women is viewed as a prerequisite for achieving effective development in the schools and in the community. The disparities that arise at school are referred to as gender issues in education and the head teacher is expected to address them in order to achieve equity. The introduction of FPE in January, 2003 raised the National Gross Enrolment Ratio 
(GER) from $88.3 \%$ in 2002 to $102.8 \%$ (105.0\% for boys and $100.5 \%$ for girls). By 2004, the GER rose further to $104.8 \%$ (108\% for boys and $101.6 \%$ for girls). The implementation witnessed a widening of gender gap in favor of boys. Gender disparities are evident in enrolment, completion, repetition, performance in KCPE and even transition to secondary level of education. National completion rates for boys are higher than for girls. Repetition rate at primary level is higher with boys than with girls. But this depends with regional differences of gender disparities. Most of the KCPE results show that generally boys register better results than girls attracting higher transition rate to secondary schools for boys than for girls.

In the MoEST Journal (July 2007), a girl child is expected to perform academically like a boy-child. Unfortunately, the girl-child has so many responsibilities at their homes i.e. domestic chores. This always deters them from doing their class work with ease. Mworia (1993) found that gender is a major issue in school performance. Some traditions lower the status of girl-child, for example, a parent can pay school fees for boy and miss or ignore for his sister. This can demoralize the girl-child. Gender concepts represent children's life experience as boys and girls. A system based on set of beliefs, opinions and behavior about masculinity and femininity can be constructed and reinforced in some institutions e.g. church, households, religious groups, school etc. Roles are instituted differently in these institutions and directly linked to traditional gender responsibilities, for example, Men had to protect and provide for the family while women cooked and looked after the children at home. All these organizations have slowly changed. The teacher has become instrumental in reinforcing the stereotyped gender roles. It's evident in schools curricula and management style where girls sweep and wash floors, while boys collected rubbish and carry water for cleaning the classrooms (Elimu Newsletter, 2009).

According to the Daily Nation (2008) girls registered a remarkable improvement in the $2008 \mathrm{KCPE}$ results. The best student country-wide was a girl with 460 marks out of 500. The results revealed that 46 out of 102 top performers were girls who also led in 5 provinces: Central, Eastern, Nairobi, Western and Coast. FPE has demonstrated the government commitment to gender equity, social and economic development. This has created opportunities for girls and boys who would not have otherwise attended school. A lot has happened to encourage the education of boys and girls in the country. This includes the Kenya Education Sector Support programme (KESSP) that has adapted a sector-wide approach. It's therefore, important that all stakeholders in education including parents, friends, media, educationists, researchers and others, support boys and girls in schooling (Elimu Newsletter, 2007).

\subsubsection{Special Education}

According to Persons with disabilities Act No. 14 (2003), no person or learning institution shall deny a disabled person admission to any course of study by any reason if a person has the ability to acquire substantial learning in the course. The FPE has taken care of all children including those with special needs. They are those who are hard of hearing, partially seeing, and cerebral palsied, crippled, mentally retarded and gifted children. They require more than usual amount of the educational services. Some are found in different special schools while others are integrated in the ordinary public primary schools. Others have their units that are found in school's compound. Unfortunately, the government has not trained enough teachers for special assignment like for the above cases. This makes the learners to be kept in primary school for the sake of it. Those children that are academically gifted have more complicated problems. The FPE does not have special programs in the curriculum for this kind of children as the programme was implemented. Teachers assign them special classes e.g. grouping or enriching their learning situations with extra work and assignments.

\subsubsection{School Going Age}

Okumbe (2007) notes that school is an industry and raw materials are the pupils in an educational organization. They are the ones who learn being the primary beneficiaries. They are the ones from whom the education objectives are achieved. The learners are animate and have to be transformed into an appropriate product. The quality cannot be judged from their external appearance. The product is judged by the way its past learners give to the society.

According to MoEST (2003) the system of education in Kenya recommends six years of age to be the school-going age. If a child has attained this age, is likely to perform because he/she is developed and mature to learn. Too young children might get tired before the end of the day. According to 
Wikipedia, an Italian educator Maria Montessori (1870-1952) found that human intelligence develops sequentially. Children proceed on their own from one stage of development to another through maturation and exploration of activities. Each stage depends on the preceding one and leads to the next.

\subsubsection{Peer Pressure}

The FPE attracted learners of all ages. According to Ornstein and Lavine (1993:332) peer pressure has turned to be very influential in primary school. Pupils learn new things, ideas and do practical activities by help or by learning from peer groups. Children choose their peer groups that can influence their learning positively or negatively. Unfortunately, some of the pupils in classes have age differences such that they cannot make a peer grouping match. Some are isolated in one way or another, Kimani Maruge Ng'ang'a, for example, who in the Guinness book of records, became the oldest standard one pupil. He was 84 years old when on $12^{\text {th }}$ January, 2004 joined Kapkendulywa Primary School in Eldoret District. He was made the head-boy of the school in the year 2005 (Wikipedia). He went to school to read and write because he wanted to be a doctor. Many other children who were over age also went back to school. Those who had dropped due to lack of school fees benefited from the FPE programs.

\subsection{Socio-Cultural Factors}

According to Wikipedia, society and culture are what enable people to communicate with one another and to function within a set of common rules. Children must therefore, learn concepts, values and behavior patterns of individuals sharing the same culture and to function first as children and then as adults. This is to make them participate effectively in groups and then in society. The FPE has been implemented for the purpose of helping determine what a child learn and how well he or she is prepared to function in society. Culture is that which binds men together; it's a way of thinking and behaving. School provides us with a sense of continuing and experience of our culture. It is where values, beliefs and norms of a society are held and passed on. Some institutions help in transmitting culture, school being one, peer group, church, mass media and family.

According to Mbiti (2007), family is the first medium for transmitting culture to the children. The family is a whole world for all young children and its members basically teach a child what matters in life. Desires of achievement and motivations to excel in school are passed on from parent to child. The behaviours that adults encourage or discourage and their provision of discipline affect the child's academic performance. Many children do well in school because their home and family environment have provided them with good preparation for succeeding. Others do poorly because they have not been well-prepared and schools have not succeeded to adjust this disadvantage.

According to Wikipedia, working mothers have various reasons for going to work e.g. better employment opportunities for women, rising divorce rates, family financial pressures and changes in traditional cultural attitudes that dictated mothers to stay at home there before. This has caused the phenomenon of latchkey-children who return to empty homes after school and sit by television or roam on the streets in urban areas. They have to feed for themselves or take care of siblings while parents work. This phenomenon has a negative effect on performance since the child does not only concentrate on his/her intellectual functioning on education, but also domestic activities. Singleparent families are homes that one headed by single parent; widow, widower, separated, divorced or a never married woman. The children from these families are likely to suffer from negative effects. The families are likely to fall in poverty and children suffer from emotional problems. This causes poor academic performance of these children at school. Child abuse signs are mostly detected by school teachers in our country. Some children are beaten or sexually harassed and suffer from serious emotional and social development. Some children are denied needs such as food, clothing or medical treatment. The relatively high proportion of abused victims is from low income families. They are not likely to perform well in school like those of high income families. Some children are exposed to some factors that cannot allow good academic performance in their lifestyles. They include some activities carried out in some homes like selling illicit brews and also drugs which affect learning negatively.

\subsection{The Teacher Factor}

According to Olembo, Wanga and Karagu (1992), a good teacher is not only a communicator of knowledge but a model of competence. He imparts certain attitudes and skills to his pupils and the society as a whole which may either invite overt reference to him or create open defiance. A teacher 
cannot, therefore, gain public esteem by demanding it. The teacher is the major facilitator in the FPE Programme to the children. Kathuri (1986) indicates that Primary School with a good quality staff is an asset to the school and can aim high at curriculum implementation and trasition as qualified teachers is the primary factor for education offered in FPE. Their experience helps them translate the syllabus into the scheme of work and then deliver to the learners. Teaching is a highly complex endeavor involving techniques and knowledge of the highest order. Awour (1987) states that the issue of availability of teachers is important and their shortage create problems in schools.

According to Ornstein and Lerine (1993), people choose to be teachers because of different reasons e.g. love for children, desire to impact knowledge, an interest in and excitement about teaching, desire to perform a valuable service to the society and job benefits e.g. salary. For whatever reason, a study in 1990 showed that $85 \%$ of teachers were generally satisfied and had been enthusiastic about teaching than when they started. Many teachers up-to-date believe that they have insufficient salaries, insufficient time for counseling learners, planning lessons and other instructional functions. Shiundu and Omulando(1992) note that given vital role in curriculum implementation, teachers need appropriate and relevant training to teach. They need guidance and encouragement. The curriculum specialist must utilize the saying that education system is greater than its teacher. This underscores the importance of a teacher to have undergone a system of teacher training and refresher programs in order to effectively deliver to the pupils. Teachers of a school must operate as a team with a common purpose and principles. Within the team there should however be plenty of scope for individual expression of personality and opinion. The FPE has not considered career progression of primary school teachers. Many of them have stagnated in a particular grade for more than 15 years for example P1 grade should be considered by the government like secondary school teachers, who move from one grade to another after 3 years. Luckily, universities have given opportunities to the teachers to upgrade themselves by offering institutional and distance learning programs. Unfortunately, many teachers cannot afford as programmes are very expensive.

According to Olembo, Wanga, Karagu (1992) the importance of in-service education programs for qualified teachers is supported by the fact that they offer quickest way of introducing changes and improvement in primary schools. Courses for those teachers who need training for new roles may be of a permanent or short-term nature. Master of Education (MED) at various universities in Kenya is an example of permanent in-service teacher education course that gives opportunities to the teachers to upgrade themselves.

The accomplishment of FPE is that it enables all children to go to school. This has resulted in high enrolments in all schools in the country. Unfortunately, the number of teachers has remained the same. Teacher shortage, therefore, has become the principal stumbling block in the implementation of FPE. Some schools are forced to combine classes while others have introduced multi-shift to cater for the increased enrolment. There has been an overstretching of teaching and learning materials. But with the FPE teacher are upbeat with provision of teaching and learning materials and that has spurred them on. Teaching and learning materials have improved their work since they are able to cover the syllabus and teach new concepts easily and faster. They are able to give assignments without writing them on the chalkboard. Lesson preparations are easier than before. However, there has been uncontrolled admissions whereby with large enrolment, there is offset in teachers' performance and morale. Teachers are overwhelmed with workload thus leaving some classes and subjects unattended fully. They also give fewer assignments to the learners (Moest 2004).

Through the implementation of FPE, majority of teachers have learnt that the level of illiteracy in Kenya is due to poverty situations. They have cited this in the high enrolled scenario after introduction of FPE. Those children who had earlier dropped out of school was not by choice but mostly due to lack of Fees. That's why even married girls left their husbands to go back to school.

\subsection{Primary School Inspection}

According to the Education Act of 1968 (Section 18), school inspectors are charged with authority to request the head teacher of the institution to place at his disposal all the facilities, records, accounts notebooks, examination scripts and any other materials belonging to the institution that he may require for the purpose of the inspection or audit. Much of the inspection in primary schools is done by QASO. The head teachers can also inspect the activities carried on in the schools. Schools that get more inspections sessions tend to perform better than those that are rarely inspected. Inspectors give 
guidance and updates of the emerging issues on FPE to the headteachers. The QASO can arrange for seminars' and workshops operations through the regional TAC. This can help to improve the teachers' attitude, mode of teaching and inform them of new innovations in the curriculum. It's the duty of the inspectors to see that the FPE Programme is being implemented. They should inspect schools regularly so that they familiarize themselves with the prevailing problems in FPE. They organize for the prize giving days where top performing schools and pupils are rewarded.

\subsection{Community Relations}

According Mbiti (1980), a school is not an Island but part of the community in which it is located. The school activities must therefore reflect as far as possible the nature and aspirations of the community. The relationship that exists between a school and the community has far reaching implications. Much influences shape school- community relationship either negatively or positively (MoEST, 2005). The nature of the relationship between the school and the community ultimately has an impact on the educational programs in the school. The head teacher can bring the school closer to the community through direct participations and giving services to the community functions (Okumbe, 1999).

The local community leaders and administration should also be involved in the school development for example sub-chiefs, chiefs and councilors can support schools by supplying facilities which the government doesn't supply through the FPE funds. Communities have the responsibility of disciplining children by reporting those who are seen roaming and idling around the villages to the school administration for action. The community should act as a watch dog to ensure that pupils are in school as every child has a right to UPE in Kenya.

\subsection{Physical Resources and Teaching/Learning Materials}

Physical facilities are an important factor in both school attendance and achievement (MoEST, 2005). They include classrooms, toilets, libraries, staff rooms and so on.. They influence the achievement of primary school goals. They give security in learning and teaching situations. It is the responsibility of the head teacher to ensure there are adequate physical resources to implement the school curriculum as they are instructed by FPE programme.

Teaching and learning materials are those that are directly used by pupils and teachers in learning process. They include textbooks, exercise books, pens, paper, wall charts, wall maps or any other improvised teaching aid. Lack or insufficiency of these materials leads to poor performance as summed up by Ranju (1973). The FPE Programme has catered for these materials and can be purchased locally through the school instructional material selections committee (SIMSC). Some can be improvised using the locally available materials considering that learning is learner-centered and they should do most of the activities.

\subsection{HIV/AIDS on FPE}

According to MoEST (2007), HIV and AIDS have been termed as a national disaster. In this era of FPE, it has taken toll on teachers thus reducing the capacity of school to handle the large number of children enrolled. Similarly, it has taken parents of school going children thus creating a large pool of orphans who are not able to attend school consistently as they lack basic needs like food and clothing especially school uniforms. Some have a lot of responsibilities of taking care of their HIV-positive parents and relatives. Such children do not concentrate on their studies and some end up dropping out of school. Some HIV-positive children are not able to attend school regularly due to their poor health followed by opportunistic diseases. The epidemic has reduced the capacity of the communities to support schools given that it has lost the very productive members of the society. HIV and AIDS have interfered with the FPE implementation. This is through the demise of teachers, parents and children decreasing the number of all. Some learners are left without care and provision of their parents and also the less number of teachers in school causing overloading.

According to KIE (1999), the FPE Programme has provided a curriculum that is able to highlight important issues on HIV and AIDS to the learners. It is important for teachers to know that AIDS messages are not only passed through infusion in other subjects, but can also be integrated into the cocurriculum and out of schools activities e.g. clubs, music, drama festivals and parents' days. There could be inclusion of HIV and AIDS message into school activities where the teacher may be alert and make use of the opportunity to pass related messages. The FPE programme has provided a 
curriculum that is able to highlight important issues on HIV and AIDS to the learners. It highlights on causes, signs and symptoms, prevention, control and care to the infected and the affected members.

\section{RESEARCH METHODOLOGY}

A survey design was used for collecting information in this study. According to Orodho (2008), survey design is where the researcher may describe the distribution of the outcome of the programme. It is concerned with gathering facts rather than manipulating the valuables. The researcher used the survey design as it deals with information from different groups and areas. The respondents included district education officer, head teachers, teachers and pupils who were given questionnaires or subjected to an interview guide. The researcher used survey design because the research was a case study where few schools were studied to represent all public primary schools in Ruiru District.

Random sampling was used to determine the respondents for the study. According to Orodho (2003), random sampling is a process of selection from a population that provides every sample of a given size an equal probability of being selected. Random sampling was used to arrive at 6 public primary schools out of the 29 schools in Ruiru District public primary schools. Head teachers of the sampled schools responded in the study. From the 6 sampled schools, 3 class 8 teachers and 20 upper primary pupils from each school were selected giving a total of 18 teachers and 120 pupils. The District Education Officer of Ruiru District also participated in the study. The study therefore comprised of 145 respondents.

\section{RESULTS AND DISCUSSIONS}

\subsection{Introduction}

This chapter presents result and discussion of the study findings. The main goal of the study was to establish why there has been low transition of pupils from primary to secondary schools in Ruiru District public primary schools despite the implementation of FPE. The findings of the study are presented based on the following research objectives.

i. To establish why pupils drop out of school before graduating in class eight hindering their transition.

ii. To establish how parents contributions towards the FPE programme enhance transition.

iii. To determine the plans laid by the head teachers and the school management committees to facilitate in transition rate of their pupils.

iv. To investigate how problems associated with FPE Implementation hinder transition of pupils.

v. To explore the impact of FPE funds in maintaining human resource, physical facilities and teaching/learning resources in enhancing transition.

Background information of the study respondents is presented first, followed by the analysis and discussions of each of the given research objectives. The study results are presented using tables, charts and bar graphs which were then discussed on basis of the literature reviewed.

\subsection{Questionnaire Return Rate}

The study sample comprised of 6 head teachers, 18 teachers, 120 pupils and 1 DEO. Of the targeted 144 respondents, all the head teachers, 18 teachers, 110 students and 1 DEO responded, giving a total of 135 respondents which is equivalent to $93.2 \%$ questionnaire return rate. This is a reliable response rate for data analysis as Mugenda and Mugenda (2003) pointed that for generalization a response rate of $50 \%$ is adequate for analysis and reporting, $60 \%$ is good and a response rate of $70 \%$ and over is excellent.

\subsection{Background Information of the Study Respondents}

Out of the 6 head teachers, $4(66.7 \%)$ were males while $2(33.3 \%)$ were females. Of the 18 teachers, $7(38.9 \%)$ were male teachers while $11(61.1 \%)$ were female teachers. Among the 110 pupils, 53 (48.2\%) were boys and $57(51.8 \%)$ were girls. Figure 4.1 illustrates pupils age. 


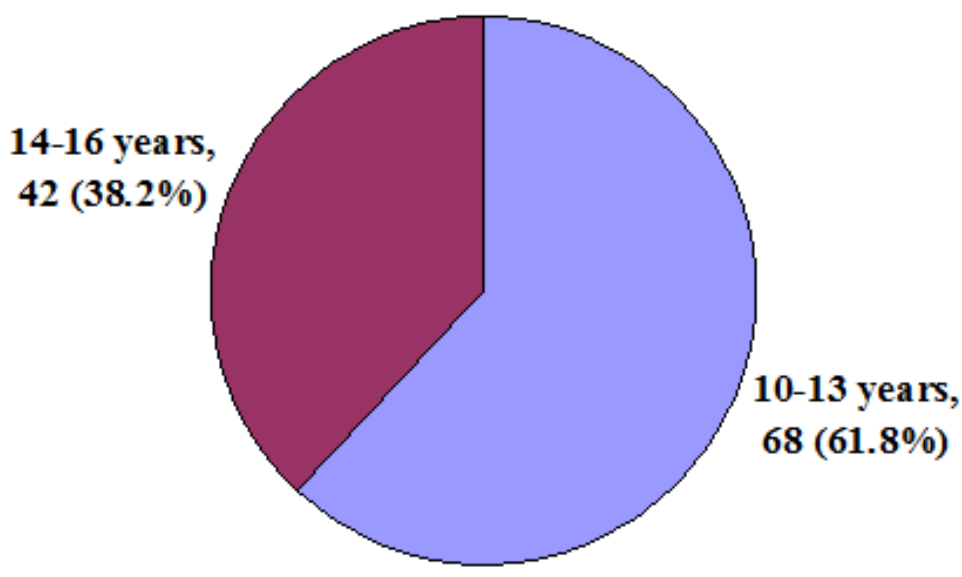

Figure4.1. Pupils' age

Figure 4.1 shows that $68(61.8 \%)$ pupils were aged between 10 and 13 years while 42 (38.2\%) pupils were aged 14-16 years. This shows that majority of pupils were below 13 years. Table 4.1 presents head teachers' and teachers' age

Table4.1. Head Teachers and Teachers' Age

\begin{tabular}{|l|l|l|l|l|}
\hline Age & Head Teachers & Percent & Feachers & \\
\cline { 2 - 6 } & Frequency & 0.0 & 3 & Percent \\
\hline $30-39$ years & 0 & 66.7 & 13 & 16.7 \\
\hline $40-49$ years & 4 & 33.3 & 2 & 72.2 \\
\hline $50-60$ years & 2 & $\mathbf{1 0 0 . 0}$ & $\mathbf{1 8}$ & 11.1 \\
\hline Total & $\mathbf{6}$ & & $\mathbf{1 0 0 . 0}$ & \\
\hline
\end{tabular}

As shown in Table 4.1 majority $(66.7 \%$ of the head teachers and $72.2 \%$ of the teachers) of the respondents were aged between $40-49$ years.

Table 4.2 shows head teachers and teachers academic qualifications.

Table4.2. Head Teachers and Teachers Academic Qualifications

\begin{tabular}{|c|c|c|c|c|}
\hline \multirow{2}{*}{$\begin{array}{l}\text { Academic } \\
\text { qualification }\end{array}$} & \multicolumn{2}{|c|}{ Head Teachers' qualification } & \multicolumn{2}{|c|}{ Teachers' qualification } \\
\hline & Frequency & Percent & Frequency & Percent \\
\hline Bachelors degree & 3 & 50.0 & 6 & 33.3 \\
\hline Diploma & 2 & 33.3 & 5 & 27.8 \\
\hline EACE/KCE & 0 & 0.0 & 2 & 11.1 \\
\hline EACE & 1 & 16.7 & 5 & 27.8 \\
\hline Total & 6 & 100.0 & 18 & 100.0 \\
\hline
\end{tabular}

Results in Table 4.2 shows that among the 6 head teachers' who took part in the study, half of them (50.0\%) had attained Bachelors degree qualification, 2 (33.3\%) had diploma qualification while 1 (16.7\%) had EACE qualifications. Results in the table further illustrates that 6 (33.3\%) teachers had Bachelor degree, 5 (27.8\%) had diploma qualifications while another $5(27.8 \%)$ had attained EACE qualifications. This shows that most of the respondents had the relevant basic qualifications. However, this does not necessarily mean they (head teachers and teachers) were effective in their work. Researchers such as Wanzare and Ward (2000) and Bundi (2008) have shown the need for continuous professional development of school administrators and teachers to improve the quality of education. Table 4.3 illustrates study respondents (head teachers and teachers) teaching experience.

Table4.3. Head Teachers and Teachers Teaching Experience 
Learners transition Rates from Primary Schools to Secondary Schools in Kenya

\begin{tabular}{|l|l|l|l|l|}
\hline \hline \multirow{2}{*}{$\begin{array}{l}\text { Teaching } \\
\text { experience }\end{array}$} & Head Teachers & Teachers \\
\cline { 2 - 5 } & Frequency & Percent & Frequency & Percent \\
\hline $6-10 \mathrm{yrs}$ & 0 & 0.0 & 2 & 11.1 \\
\hline $11-15 \mathrm{yrs}$ & 0 & 0.0 & 1 & 11.1 \\
\hline $16-20 \mathrm{yrs}$ & 0 & 0.0 & 2 & 44.4 \\
\hline $21-25 \mathrm{yrs}$ & 2 & 33.3 & 8 & 27.8 \\
\hline Over $25 \mathrm{yrs}$ & 4 & 66.7 & 5 & $\mathbf{1 0 0 . 0}$ \\
\hline Total & $\mathbf{6}$ & $\mathbf{1 0 0 . 0}$ & $\mathbf{1 8}$ & \\
\hline
\end{tabular}

As indicated in Table 4.3, majority $(66.7 \%)$ of the head teachers had taught for over 25 years while most (44.4\%) of the teachers had taught 21-25 years. This shows that most of the teachers had a long time experience in teaching field to be in a position of giving credible information on factors that led to low transition of learners from primary to secondary schools.

Figure 4.2 reflects head teachers' experience as a school administrator

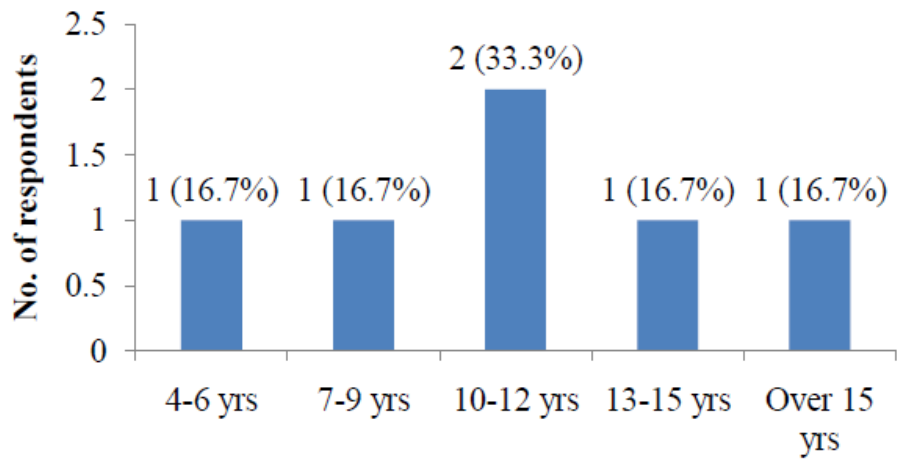

Duration served as a school headteacher

Figure4.2. Headteachers' Experience as a School Administrator

Figure 4.2 shows that majority (66.7\%) of the headteachers' had served in headship for 10 years and above.This shows that majority of the headteachers had served long enough and therefore were expected to give administrative challenges they encounter in relation to management of FPE fund in school.

\subsection{Factors Hindering Pupils Graduation in Class Eight}

One goal of the study was to establish why pupils drop out of school before graduating in class eight. To address this objective, the study first sought to find out whether class seven and eight teachers had recorded any dropout cases for the last three years. Secondly, the study sought to find out from the teachers and pupils some of the factors which influenced pupils' retention in schools hence resulting to school dropout. Figure 4.3 illustrates teachers' responses on the average number of learners who had dropped out of school for the last 3 years in class seven and eight.

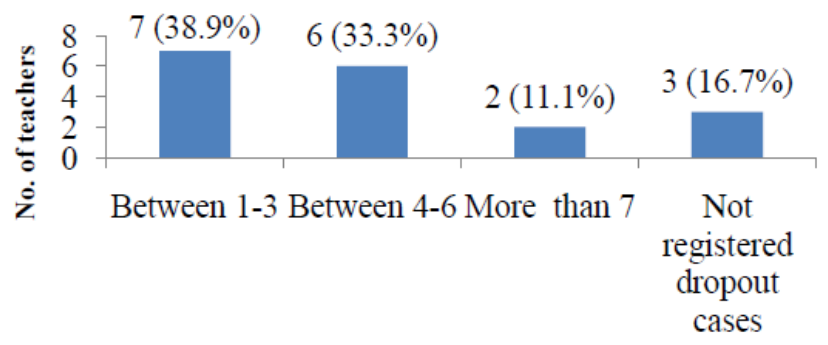

An average number of learners who had dropped out of school

Figure4.3. Average Number of Learners who had Dropped out of School 
Figure 4.3 shows that 7 teachers reported that for the last three years, they recorded between 1 and 3 cases of learners dropping out of school, 6 teachers registered between 4 and 6 cases while 2 recorded more than 7 cases. This show that cases of pupils dropping out of school from Ruiru district was a reality despite the government introduction of free primary education. Table 4.4 shows teachers' responses on reasons that lead to school dropout among pupils.

Table4.4. Teachers' Responses on Reasons that Lead to School Dropout among Pupils

\begin{tabular}{|l|c|c|}
\hline Reasons for dropping out of school & Frequency & Percent \\
\hline Poverty & 7 & 38.9 \\
\hline Indiscipline & 5 & 27.8 \\
\hline Child labour & 2 & 11.1 \\
\hline Negligence by teacher & 1 & 5.6 \\
\hline No dropout cases & 3 & 16.7 \\
\hline Total & $\mathbf{1 8}$ & $\mathbf{1 0 0 . 0}$ \\
\hline
\end{tabular}

From Table 4.4, it can be observed that 7 (38.9\%) teachers were of the view that pupils dropped out of school due to poverty, 5 (27.8\%) felt that indiscipline was the major reason while $2(11.1 \%)$ indicated that child labour contributed to learners' dropping out of school. Only $1(5.6 \%)$ teacher stated that teachers' negligence caused learners to drop out of school. According to the DEO Ruiru district, the major factors that influenced learners' to drop out of school were indiscipline, peer pressure, poverty, parents and teachers negligence.

Table 4.5 presents responses given by the pupils.

Table4.5. Reasons for Dropping out of School as Reported by Pupils

\begin{tabular}{|l|l|l|l|l|}
\hline \multirow{2}{*}{ Reasons for dropping out of school } & Yes & No & \\
\cline { 2 - 5 } & f & \% & f & \% \\
\hline Poverty & 93 & 84.5 & 17 & 15.5 \\
\hline Lack of parental support & 80 & 72.7 & 30 & 27.3 \\
\hline Indiscipline & 77 & 70.0 & 33 & 30.0 \\
\hline Lack of interest in education & 62 & 56.4 & 48 & 43.6 \\
\hline Lack of role models in the society & 54 & 49.1 & 56 & 50.9 \\
\hline Poor academic performance & 41 & 37.3 & 69 & 62.7 \\
\hline Child labour & 39 & 35.5 & 71 & 64.5 \\
\hline Peer influence & 25 & 22.7 & 85 & 77.3 \\
\hline
\end{tabular}

As shown in Table 4.5, over $70.0 \%$ of the pupils reported that poverty, lack of parental support and indiscipline were the major factors which influenced pupils to drop out of school before graduating in class eight. In addition to this, $49.1 \%$ of the students cited that there were no role models in the society and also some pupils engage in peer groups (22.7\%) which influenced them negatively hence dropping out of school. Other reasons that were highlighted by a notable number of respondents were pupils' lack of interest in education, poor academic performance and child labour. In agreement with the findings, previous studies have shown that there are often precursors to dropping out, where children could be seen to be at risk or vulnerable to early withdrawal (Hunt, 2008; Lewin 2008; Ampiah and Ada-Yeboah, 2009). These include grade repetition, low achievement, over age enrollers and children who have regular absence or previous temporary withdrawals from school. In addition to this, indiscipline is another factor which influence learner to drop out of school. According to Okumbe (2001), school discipline is a system of arranging conditions for healthy learning. If a learner develops bad behaviour in school he or she is expelled or suspended out of schools. This negatively influences school attendance which may contribute to school dropout. Poverty also appears to influence the demand for schooling not only because it affects the inability of households to pay school fees and other cost associated with education but also because it is associated with a high opportunity cost of schooling for children. Students who miss school fall behind their peers in the 
classroom. This, in turn, leads to low self-esteem and increases the likelihood that at-risk learners drop out of school.

\subsection{Establish how Parents Contributions Towards the FPE Programme Enhance Transition}

Parents' contribution is very important in many aspects of education. In this regard the second objective of the study sought to establish how parents' contributions towards the FPE programme enhance transition. To ascertain this, the researcher asked the head teachers to rate the support they receive from parents towards FPE programme. Figure 4.4 shows their responses.

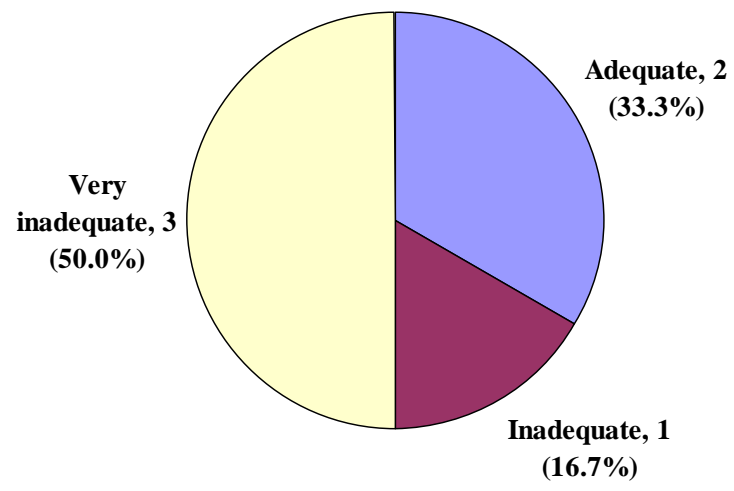

Figure4.4. Head Teachers' Ratings of Parental Support Towards FPE Programme

As depicted in Figure 4.4, 1 (16.7\%) head teacher felt that parents were offering adequate support towards FPE programme in school, $3(50.0 \%)$ were of the view that the support they were receiving from parents was inadequate while $2(33.3 \%)$ indicated that it was very inadequate. This shows the support given by the parents to the school was not adequate, which may prove to be disadvantageous in the school implementation of free primary education. According to Lezotte (2001), family and community involvement is a general term used to describe a myriad of activities, projects, and programs that bring parents, business men and women, and other stakeholders together to support student learning and schools. Families and other adults can be involved in the education of young people through a variety of activities that demonstrate the importance of education and show support and encouragement of students learning. Table 4.6 shows parents' contribution towards FPE as reported by head teachers.

Table4.6. Head Teachers' Responses on Parents' Contribution Towards FPE

\begin{tabular}{|l|l|l|}
\hline Parents contribution & Frequency & Percent \\
\hline Financial support & 2 & 33.3 \\
\hline Maintaining children discipline & 3 & 50.0 \\
\hline Donation of resources & 1 & 16.7 \\
\hline Total & $\mathbf{6}$ & $\mathbf{1 0 0 . 0}$ \\
\hline
\end{tabular}

As shown in Table 4.6, 2 (33.3\%) head teachers pointed out that some parents contributed financially towards school development. This development includes the physical structure of the school such as classrooms, administration offices and the sanitation facilities. It also comprises of repairing and maintaining the existing physical structures such as desks, chairs and tables. However, lack enough of fund in the school may undermine school development in terms of inadequate classrooms, inadequate sanitation facilities and other facilities such as desk, chairs and tables. Consequently, this could lead to unconducive learning environment (due to factors such as overcrowding in classroom; and poor hygiene) which could negatively influences learners hence dropping out of school. Half of the respondents $(50.0 \%)$ further indicated that some parents ensured that their children were well disciplined and therefore cases such as high rate of absenteeism in school and incompletion of assignment, which could lead to school dropout, were rarely experienced. The results of the analysis also revealed that $1(16.7 \%)$ head teacher reported that some parents donated some of their resources in schools to ensure that children were retained in schools and hence minimizing drop out cases. For instance, in school that had school feeding programmes, some parents negotiated with the school to give out their farm products at low cost therefore ensuring the continuation of the programme in school.

\subsection{Plans Laid Down in School to Facilitate Learners Transition Rate}


The third objective of the study was to determine the plans laid down by the head teachers and the school management committees to facilitate in transition rate of their pupils. To respond to this objective, school heads were asked to give some of the school policies that were laid down in their current schools to ensure learners transition. Table 4.7 shows their responses

Table4.7. Strategies Employed by Head Teachers and the School Management Committees to Facilitate Transition Rate of Pupils

\begin{tabular}{|c|c|c|}
\hline Plans laid down in school & Frequency & Percent \\
\hline Ensuring conducive teaching and learning environment & 5 & 83.3 \\
\hline Introduction of school feeding programmes & 4 & 66.7 \\
\hline Offering of guidance and counseling to children & 4 & 66.7 \\
\hline $\begin{array}{l}\text { Organizing and holding discussion with parents on children academic } \\
\text { progress while at school and home }\end{array}$ & 3 & 50.0 \\
\hline Parents and community involvement in school activities & 3 & 50.0 \\
\hline $\begin{array}{l}\text { Organizing and holding discussion with parents on children behavior } \\
\text { while at school }\end{array}$ & 2 & 33.3 \\
\hline Appeal to well wishers to sponsor needy students & 2 & 33.3 \\
\hline
\end{tabular}

Table 4.7 shows that majority $(83.3 \%)$ of the head teachers ensured that there is conducive teaching and learning environment in school to ensure learners retention while in school. Four (66.7\%) school heads reported that their schools had introduced school feeding programmes. The major reason being school feeding programmes enhances retention of learners especially those from low income families. Recent evaluations of such programs (Ahmed, 2004; Vermeersch and Kremer, 2004) have shown that school feeding can lead to increased access of learners, reduced dropout, particularly in the lower primary school grades, and improved students' learning. Another similar proportion (66.7\%) of the respondents cited that their schools offered guidance and counseling among learners. According to the recommendations of the report of the Task Force (MoEST, 2001), Recommendation 8 (a), the Ministry of Education recommends that Guidance and Counselling in schools be strengthened at the teacher and peer level. Therefore, if Guidance and Counselling is effectively and efficiently carried out by expert teachers as recommended by the Ministry of Education, it can greatly assist in eradicating many indiscipline problems in the schools which may lead to cases such as school dropout. Other strategies that were laid down by school head teachers and management committee were organizing and holding discussions with parents on pupils' behavior and academic progress while in and outside the school. However, based on the study findings, it emerged that while half $(50.0 \%)$ of the respondents indicated that they held discussions on pupils academic progress, only $33.3 \%$ of them indicated that they discussed about pupils behavior. This clearly shows that some schools were not fully involving parents on issues related to learners progress while in schools. This could negatively influence children learning and hence leading to school dropout. This therefore, calls for an improvement in teachers' involvement of parents while dealing with children behavior and also during discussion of learners' progress in education.

\subsection{Influence of Problems Associated with Implementation of FPE on Learners Transition}

The fourth objective of the study was to investigate how problems associated with FPE Implementation hinder transition of pupils. To address this objective, teachers and head teachers were given with statements measuring problems associated with FPE and their impacts towards pupils' transition from primary to secondary school. They were expected to indicate their agreement and disagreement levels on a 4-point likert scale, ranging from strongly agree to strongly disagree. Table 4.8 shows head teachers responses.

Table4.8. Head Teachers' Responses on the Problems Associated with FPE and Learners Transition

\begin{tabular}{|l|l|l|l|l|l|l|l|l|}
\hline Challenges associated with implementation of FPE & \multicolumn{2}{l|}{ SA } & \multicolumn{2}{l|}{ A } & \multicolumn{2}{l|}{ SD } \\
\cline { 2 - 9 } & f & \% & f & \% & f & \% & f & \% \\
\hline $\begin{array}{l}\text { Inadequate classroom have led to overcrowding of the pupils } \\
\text { while in classroom }\end{array}$ & 2 & 33.3 & 3 & 50.0 & 1 & 16.7 & 0 & 0.0 \\
\hline Inadequate teaching and learning resources negatively & 4 & 66.7 & 2 & 33.3 & 0 & 0.0 & 0 & 0.0 \\
\hline
\end{tabular}




\begin{tabular}{|l|l|l|l|l|l|l|l|l|}
\hline \hline influences pupils academic performance & & & & & & & \\
\hline Understaffing have led to heavy workload among teachers & 3 & 50.0 & 2 & 33.3 & 1 & 16.7 & 0 & 0.0 \\
\hline $\begin{array}{l}\text { Inadequate sanitation facilities have led to poor hygiene in } \\
\text { school hence influencing pupils retention in school negatively }\end{array}$ & 1 & 16.7 & 2 & 33.3 & 2 & 33.3 & 1 & 16. \\
\hline
\end{tabular}

Key: $S A=$ Strongly Agree, $A=$ Agree, $D=$ Disagree, $S D=$ Strongly Disagree

School resources have been observed as a potent factor to better education. This is because their availability, adequacy and relevance influence efficiency and high productivity among learners. Learners' productivity is measured in terms of the academic performance, retention in school and also transition rate from one level to another. As shown in Table 4.8, over $70.0 \%$ of the head teachers agreed (combined strongly agree and agree) that inadequate classroom, inadequate teaching/ learning resources and understaffing were some of the major problems associated with implementation of FPE programme. This shows that most of the schools were not adequately equipped with teaching and learning materials and other infrastructural facilities. As a result, this could negatively influence learners' academic progress which would translate to low transition rate of learners from primary to secondary school. Table 4.9 presents teachers responses on the problems associated with FPE and learners transition.

Table4.9. Teachers' Responses on the Problems Associated with FPE and Learners Transition

\begin{tabular}{|l|l|l|l|l|l|l|l|l|}
\hline Challenges associated with implementation of FPE & \multicolumn{2}{l|}{ SA } & \multicolumn{2}{l|}{ D } & \multicolumn{2}{l|}{ SD } \\
\cline { 2 - 8 } & $\mathbf{f}$ & $\mathbf{\%}$ & $\mathbf{f}$ & $\mathbf{\%}$ & $\mathbf{f}$ & $\mathbf{\%}$ & $\mathbf{f}$ & $\mathbf{\%}$ \\
\hline Understaffing have led to heavy workload among teachers & 15 & 83.3 & 3 & 16.7 & 0 & 0.0 & 0 & 0.0 \\
\hline $\begin{array}{l}\text { Inadequate classroom have led to overcrowding of the pupils } \\
\text { while in classroom }\end{array}$ & 11 & 61.1 & 7 & 38.9 & 0 & 0.0 & 0 & 0.0 \\
\hline $\begin{array}{l}\text { Inadequate teaching and learning resources negatively } \\
\text { influences pupils academic performance }\end{array}$ & 8 & 44.4 & 10 & 55.6 & 0 & 0.0 & 0 & 0.0 \\
\hline $\begin{array}{l}\text { Inadequate sanitation facilities have led to poor hygiene in } \\
\text { school hence influencing pupils retention in school }\end{array}$ & 5 & 27.8 & 6 & 33.3 & 4 & 22.2 & 3 & 16.7 \\
\hline
\end{tabular}

Key: $S A=$ Strongly Agree, $A=$ Agree, $D=$ Disagree, $S D=$ Strongly Disagree

Results in Table 4.9 illustrates that $83.3 \%$ of the teachers strongly agreed that understaffing have led to heavy workload among teachers. This as a result would lead to poor coverage of the syllabus which could negatively influence pupils' academic performance. Low grades in academic performance may eventually lead to pupils' dropout and hence school registers low learners transition rate. In addition, $61.1 \%$ of the teachers strongly agreed that inadequate classroom have led to overcrowding of pupils while in classroom. This as a result interferes with the capacity of the children to learn and teachers to teach (O'Sullivan, 2006). This is because overcrowding leads to little or no access to the teaching and learning materials which are critical for the development of basic skills and competencies. Based on the findings presented above, it emerged that understaffing, inadequate classrooms, inadequate teaching/learning resources and inadequate sanitation facilities had a negative impact towards pupils learning. This as a result influences learners' academic performance, retention in school and transition rates from one level to another.

To confirm head teachers' and teachers' responses on problems associated with implementation of FPE, the DEO reported that after the introduction of FPE by the government, there was a great increase on pupils' enrollment in primary schools. However, the government did not check on the resources available in schools and therefore most of the schools faced challenges after the implementation of the programme. The most inadequate resources were teachers, classrooms, teaching and learning materials, and sanitation facilities. The DEO further added that the available resources were not in good condition. This as a result could negatively influence learners' academic performance, retention in school and eventually leads to low transition rate in secondary schools.

\subsection{Impact of FPE Funds in Maintaining Human Resource, Physical Facilities and Teaching/Learning Resources in Enhancing Transition}

The fifth study objective was to explore the impact of FPE funds in maintaining human resource, physical facilities and teaching/learning resources in enhancing transition. To respond to this objective, school heads were given statements measuring the impact of FPE funds in school running and learners' transition from primary to secondary school. They were expected to indicate their agreement and disagreement levels on a 4-point likert scale, ranging from strongly agree to strongly disagree. Presented in Table 4.10 are responses obtained from the head teachers. 
Table4.10. Impact of FPE Funds in School as Reported by Head Teachers

\begin{tabular}{|c|c|c|c|c|c|c|c|c|}
\hline \multirow[t]{2}{*}{ Impact of FPE funds } & \multicolumn{2}{|c|}{$\mathbf{S A}$} & \multicolumn{2}{|c|}{$\mathbf{A}$} & \multicolumn{2}{|c|}{$\mathbf{D}$} & \multicolumn{2}{|c|}{ SD } \\
\hline & $\mathbf{f}$ & $\%$ & $\mathbf{f}$ & $\%$ & $\mathbf{f}$ & $\%$ & $\mathbf{f}$ & $\%$ \\
\hline $\begin{array}{l}\text { The school cannot afford to buy enough teaching/learning } \\
\text { resources for pupils and teacher, leading to dismal performance }\end{array}$ & 5 & 83.3 & 1 & 16.7 & 0 & 0.0 & 0 & 0.0 \\
\hline $\begin{array}{l}\text { Delay in government disbursement of funds has led the school } \\
\text { to incur large debts that limit effectiveness of school teaching } \\
\text { and learning process. }\end{array}$ & 4 & 66.7 & 2 & 33.3 & 0 & 0.0 & 0 & 0.0 \\
\hline $\begin{array}{l}\text { Lack of enough funds has led to poor maintenance of the } \\
\text { existing physical resources in school hence leading to } \\
\text { unconducive teaching/learning environment }\end{array}$ & 3 & 50.0 & 3 & 50.0 & 0 & 0.0 & 0 & 0.0 \\
\hline $\begin{array}{l}\text { Inadequate finances has led to the schools in ability to hire more } \\
\text { SMC teachers who could assist and help to minimize teachers } \\
\text { heavy work load }\end{array}$ & 2 & 33.3 & 6 & 66.7 & 0 & 0.0 & 0 & 0.0 \\
\hline
\end{tabular}

Key: $S A=$ Strongly Agree, $A=$ Agree, $D=$ Disagree, $S D=$ Strongly Disagree

Table 4.10 shows that all (100.0\%) the study respondents agreed (combined strongly agree and agree) with the following statements: school cannot afford to buy enough teaching/learning materials for pupils and teachers leading to dismal performance; delay in government disbursement of funds has led the school to incur large debts that limit effectiveness of the schools in teaching and learning process; and lack of enough funds have led to poor maintenance of the existing physical resources in school hence leading to unconducive teaching/learning environment. This clearly shows that FPE fund allocated by the government in every primary school was not adequate to cater for human resource, physical facilities and teaching / learning resources. This destabilizes school management since school finances determines the way the school is managed and whether or not the school is bound to meet its objectives. Financial management caters for proper usage of personnel, facilities, equipment and all the other factors that are involved in accomplishing the educational objectives (Orlosky et.al, 1984).

\section{CONCLUSION AND RECOMMENDATIONS}

\subsection{Summary of the Study Findings}

The main goal of the study was to establish why there has been low transition of pupils from primary to secondary schools in Ruiru District public primary schools despite the implementation of FPE. Data for the study was collected from 6 head teachers, 18 teachers, 110 pupils and 1 DEO, giving a total of 135 respondents. The following are the main study findings:-

\subsubsection{Factors Hindering Pupils Graduation in Class Eight}

The study established that the major factors which influenced pupils to drop out school before graduating in class eight were poverty, lack of parental support and indiscipline. Other factors that were mentioned included; child labour, lack of role models in the society and peer pressure.

\subsubsection{Establish how Parents Contributions Towards the FPE Programme Enhance Transition}

In relation to this objective, the study established that some parents contributed in terms of financial support, maintaining of children discipline and donation of resources. The study findings revealed that half of head teachers pointed out that some parents maintained students discipline with a few reporting that some supported school development and also donated resources like farm product under low cost. However, $83.3 \%$ were of the view that the support they were receiving from parents was inadequate.

\subsubsection{Plans Laid Down in School to Facilitate Learners Transition Rate}

The study found out that over $60.0 \%$ of the headteachers reported that the major plans laid down in school to facilitate learners' transition were; ensuring that there is conducive teaching and learning environment in school to ensure learners retention while in school; introduction of school feeding programme and offering of guidance and counseling among learners. Other strategies that were laid down by school headteachers and management committee were organizing and holding discussions with parents on pupils' behavior and academic progress while in and outside the school. However, the study findings revealed that while half $(50.0 \%)$ of the respondents indicated that they held 
discussions on pupils academic progress, only $33.3 \%$ of them indicated that they discussed about pupils behavior. This clearly shows that some schools were not fully involving parents on issues related to learners progress while in schools. This could negatively influence children learning and hence leading to school dropout. This therefore, calls for an improvement in teachers' involvement of parents while dealing with children's behavior and also during discussion of learners' progress in education.

\subsubsection{Influence of Problems Associated with Implementation of FPE on Learners Transition}

Result findings revealed that understaffing, inadequate classrooms, inadequate teaching/learning resources and inadequate sanitation facilities had a negative impact towards pupils learning. This as a result influences learners' academic performance, retention in school hence low transition rates from one level to another.

\subsubsection{Impact of FPE Funds in Maintaining Human Resource, Physical Facilities and Teaching/Learning Resources in Enhancing Transition}

The study established that FPE fund allocated by the government in every primary school was not adequate to cater for human resource, physical facilities and teaching / learning resources. All the head teachers reported that; school cannot afford to buy enough teaching/learning materials for pupils and teachers leading to dismal performance; and lack of enough funds have led to poor maintenance of the existing physical resources in school hence leading to unconducive teaching/learning environment. They further reported that delay in government disbursement of funds has led the school to incur large debts that limit effectiveness of the schools in teaching and learning process.

\subsection{Conclusion}

Based on the study findings as summarized above, the study concluded that introduction of FPE programme in schools had a great impact towards education in terms of learners' academic performance, retention in school and transition rate from one level to another. The study established that fund released by the government was not adequate to cater for human resource, physical facilities and teaching / learning resources. The results of the analysis revealed that there was shortage of; staffs, teaching and learning materials, sanitation facilities and classrooms, meaning that free primary education stretched out school resources. This undermined the quality of education offered in schools therefore negatively influencing learners' academic performance. In addition to this, the study concluded that poverty, lack of parental support and indiscipline were other major factors which influenced pupils' retention in school. However, to ensure learners graduation in class eight and transition in secondary school, the study concluded that some schools introduced school feeding programmes to enhance retention, some offered guidance and counseling to pupils as a way of curbing indiscipline while others involved parents in pupils' learning progress.

\subsection{Recommendations of the Study}

Arising from the study findings, the following recommendations were made:-

i. The government should allocate adequate funds to schools to ensure that free primary education programme run smoothly without compromising quality of education which eventually influence learners' transition rate from one level to another.

ii. Since the study established that indiscipline was one of the major factor which led to learners' dropping out of school, teachers should involve parents not only on academic issues but also on issues related to pupils discipline.

iii. The study found out that support offered by the parents was not adequate to enhance pupils' education. The study therefore suggests that parents and community members should fully support children education and school development projects.

\subsection{Suggestions for Further Studies}

This study was carried out in Ruiru Municipality. Similar studies should be carried out in other districts to find out whether the same findings would be obtained. 


\section{REFERENCES}

[1] Ahmed, A. U. (2004). Impact of Feeding Children in School: Evidence from Bangladesh. Washington, DC: International Food Policy Research Institute.

[2] Ampiah G.J \& Adu-Yeboah C. (2009). "Mapping the incidence of school dropout: acase study of communities in Northern Ghana' Comparative Education, Vol.45: Issue 2,pp219-232.

[3] Bakadha.S. (2010).Management and Evaluation of Schools, Oxford University Press Nairobi.

[4] Bishop G. (1994). Alternative Strategies for Education. London: Macmillan Publishers.

[5] Bisika, J.J. (2005). Free Primary Education Challenges for Malawi, a paper presented at National Conference Education in Lilongwe Malawi, University of Malawi, Rincellar College, Zomba, Malawi.

[6] Chiuri, L.W. \& Kiumi, J.K.(2005). Planning and Economics of Education, Egerton University: Pangolin Publishers Ltd.

[7] Daily Nation Newspaper (13 $3^{\text {th }}$ July 2003) Nairobi, Kenya.

[8] Daily Nation Newspaper (30 $30^{\text {th }}$ December 2008) Nairobi, Kenya.

[9] Dale, E. (1969). Audiovisual Methods in Teaching, Illinois, Dry Den Press.

[10] Elimu News (January - April 2009). A newsletter of the ministry of Education.Government Printers, Nairobi, Kenya.

[11] Elimu News, (December 2007). A newsletter of the ministry of Eduction. Government

[12] Fufunwa, A.B. \& Aisiku, J.U. (1982).Education in Africa; A comparative survey.London: G. Allen and Unwin.

[13] Griffins, G. (1994). School Mastery Straight Talk About Boarding Schools Management in Kenya. Lactern Publishers, Nairobi, Kenya.

[14] Hunt, F. (2008).' Dropping out from school': A cross- country review of literature. Create pathway to access No 16. Consortium for Research on Educational Access, Transitions and Equity: University of Sussex.

[15] Kathuri, N. (1996). Factors Influencing the Performance of CPE, University Press, Nairobi.

[16] Kemmerer, F. (1994). Utilizing Education and Human Resources Sector Annual analysis. Paris. UNESCO.

[17] Kombo, D.K. (2005). Sociology of Education. Adprint Nairobi, Kenya.

[18] Lewin K.M. (2008). 'Access, Age \& grade.' Create policy briefs No.2. Consortium for Research on Education Access, Transitions \& Equity: University of Sussex.

[19] Lezotte, L. (2001). Correlates of Effective Schools: The first and second generation. Okemos. MI. Effective Schools Products, Ltd.

[20] Little John.S.W(1983).Theories of human communication. Belmont,Wadsworth Publishing Company.

[21] Mbiti,D.M.(2007).Foundation of Schools Administration,Oxford University Press. Nairobi, Kenya.

[22] MoEST (2003). A handbook of Financial Management Instructions for Educational Institution. Government Printers. Nairobi, Kenya.

[23] MoEST (2003). Free Primary Education. Goverment Printers, Nairobi,Kenya.

[24] MoEST (2005). Challenges of Implementing FPE. Government Printer,Nairobi, Kenya.

[25] MoEST(2005). Handbook of Financial Management Instructions for Primary Schools. Government Printer,Nairobi, Kenya.

[26] Muchira,F.(1988). Leadership Effectiveness in Primary Colleges in Kenya, Study of leadership Style, Job Satisfaction and Student Achieveness Halifox,Nova Scotia, Unpublished PHD Thesis, Dalhousine University.

[27] Mugenda, O. M. and Mugenda, A. G. (2003): Research Methods: Quantitative and Qualitative Approaches. Nairobi: Acts Press.

[28] Mwiria, K. and Wamahiu, S. (1996): Issues in educational research in Africa. East Africa Educational Publishers, Nairobi. 
[29] Mworia, R.N. (1993). Performance I, $n$ the Kenya Certificate of Primary Education (KCPE) A Case Study of Central Imenti District. Nairobi, Unpublished Research Paper, Kenyatta University.

[30] Narc Manifesto. (2002). Democracy and Empowerment, Nairobi, Kenya.

[31] Ndurumo, M.M. (1993). Exceptional Children, Longman Nairobi, Kenya.

[32] O'Sullivan, M. (2006). Teaching large class sizes: The international evidence and a discussion of some good practice in Ugandan primary schools. International Journal of Educational Development, 26, 24-37.

[33] Okumbe, J. A. (2001). Human Resource Management: An Educational Perspective. Nairobi: Educational Development and Research Bureau. Printers, Nairobi Kenya.

[34] Okumbe, J.A. (2007). Educational management; theory and practice, University Press, Nairobi.

[35] Olembo, J.O. Wanga P.E. \& Karagu M.N. (1992). Management in Education Research and Publication. Nairobi: General Printer.

[36] Orlosky, D. E., McCrery, L. E., Shipiro, A. \& Webb, L. D. (1984). Educational Administration Today. Columbus: Charles Merril Co.

[37] Ornstein, A.C. and Lavine, D.U. (1993: 332). Foundations of Education, Houghton, Mifflin Company USA.

[38] Orodho, J.A. (2005). Elements of Education and Social Science Research Methods, Masola Publishers, Nairobi.

[39] Oumer, J. (2008). The Challenges of Free Primary Education in Ethiopia, College of Education. University of Addis Ababa International Institute for Educational Planning.

[40] Ranju, B.M. (1973). Education in Kenya: problems and perspective in educational planning \& administration. Nairobi, Kenya.

[41] Republic of Kenya (1968). The Kenya Education Act 1968. Government Printer,Nairobi,Kenya.

[42] Republic of Kenya (2001), Report of the task force on student discipline and unrest in secondary schools, Nairobi, Government Printer.

[43] Republic of Kenya (2003). Persons with Disability act No.14. Government Printer,Nairobi, Kenya.

[44] Republic of Kenya (2004). Kenya Gazette Supplement Act 2003. Government Printer,Nairobi, Kenya.

[45] Republic of Kenya (2004). National Action Plan on Education for all (2003-2005) Government Printer, Nairobi, Kenya.

[46] Republic of Kenya (2007). Ministry of Education, Gender Policy in Education. Government Printer,Nairobi,Kenya.

[47] Republic of Kenya (2008). Education Sector Report: Realizing Vision 2030 goals through effective and efficient public spending. Government Printer, Nairobi Kenya.

[48] Rindel, A. (2002). Learning needs of ministries of education in swamp environments. Paper presented at IIEP seminar on recent issues in Education Planning IIEP UNESCO, Paris.

[49] Shiundu, J.O \& Omulando, S.J. (1992). Curriculum theory and practice in Kenya. Nairobi: Oxford University Press.

[50] Sifuna, D.N. (1996). Development of education in Africa. Nairobi: Initiatives Ltd.

[51] Sorobea, N.B. (1992). A history of modern education in Kenya. Nairobi: Evans Brothers (K) Ltd.

[52] UNESCO (2002). Global Monitoring Unit. The 2002 Education for all Global Monitoring Unit. Nairobi, Kenya.

[53] UNESCO (March, 2005). Challenges in implementing FPE in Kenya Assessment Report. Nairobi, Kenya.

[54] Vermeersch, C \& Kremer, M. (2004). Schools Meals, Educational Achievement and School Competition: Evidence from a Randomized Evaluation. Policy Research Working Paper No. 2523, Washington, DC: World Bank.

[55] Wanzare, Z. and Ward, K. L. (2000). Rethinking Staff Development in Kenya: Agenda for the First Century; International Journal of Educational Development, 14 (6), 265 - 275.

[56] Wiersma (1985), Research Method in Education, Allyn and Bacon Inc. Boston Wikipedia: the free encyclopedia. 


\section{AUTHORS' BIOGRAPHY}

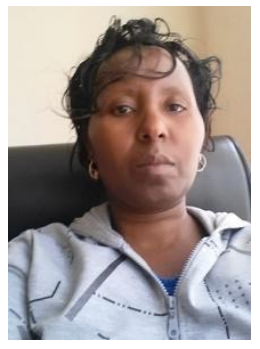

Josephine Kagwiria Kirimi, attained B.ED. (Hons) degree in 1994 from Moi University, M.Ed. (Curriculum Studies) in 2007 from Kenyatta University. Doctor of Philosophy candidate at Mount Kenya University (Curriculum Studies) since 2013 to date. She is a lecturer and chair, Department of Educational Management and Curriculum Studies from 2010 to date Mount Kenya University. She has authored a book "Challenges of curriculum implementation with Lambert Publisher, Germany, she authored and co-authored many journal articles, book chapter. She has attended and presented many academic papers at conferences and workshops. She has developed modules in Curriculum development and introduction to environmental education. She has chaired development of curriculum for various programmes in the department. She is a church leader. She is married with two children.

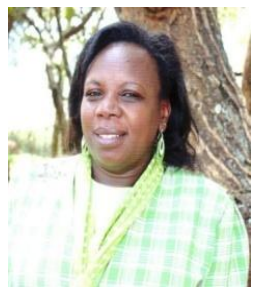

Beatrice Waiyego Ndirangu, attained a P1 certicate from Meru Teachers College in 1989. She attained B.Ed. (Hons) degree from Kenyatta University in 2008. She attained M.ED. in Educational planning. Management and administration in 2014 from Mount Kenya University. She has co-authored a paper. She is a deputy Headteacher in Gitothua Primary School in Ruiru Kenya. She is married with three children. 